$\mathrm{Pl}$ at anoi d I eaves from Cenomani an to Tur oni an $M$ kasa For mat $i$ on, nor ther $n$ Japan and thei $r$ mode of occurrence

\begin{tabular}{|l|l|}
\hline 著者 & $\begin{array}{l}\text { Nar i t a At suf um, Yamada Toshi hi ro, Nat sumbt o } \\
\text { M dor i }\end{array}$ \\
\hline $\begin{array}{l}\text { j our nal or } \\
\text { publ i cat i on t i t l e }\end{array}$ & Pal eont ol ogi cal Resear ch \\
\hline vol une & 12 \\
\hline number & 1 \\
\hline page $r$ ange & $81-88$ \\
\hline year & 2008 04 30 \\
\hline URL & ht t p: //hdl . handl e. net /2297/14543 \\
\hline
\end{tabular}




\title{
Platanoid leaves from Cenomanian to Turonian Mikasa Formation, northern Japan and their mode of occurrence
}

\author{
ATSUFUMI NARITA ${ }^{1}$, TOSHIHIRO YAMADA ${ }^{2, *}$ AND MIDORI MATSUMOTO $^{3}$ \\ ${ }^{1}$ Laboratory of Ecological and Systematic Botany, Graduate School of Agriculture, Hokkaido University, Hokkaido, 060-8589, Japan \\ ${ }^{2}$ Division of Life Sciences, Graduate School of Natural Science and Technology, Kanazawa University, Kanazawa 920-1192, Japan \\ (e-mail: ptilo@mb.infoweb.ne.jp) \\ ${ }^{3}$ Department of Earth Science, Graduate School of Science, Chiba University, Chiba, 263-8522, Japan \\ * Author for correspondence
}

Received February. 23, 2007; Revised manuscript accepted November 16, 2007

\begin{abstract}
Ettingshausenia cuneifolia is reported from the Cenomanian to Turonian Mikasa Formation of central Hokkaido. These leaves occur exclusively in carbonaceous mudstone deposited in either lagoon or marsh. Based on their mode of occurrence, these remnants may have been trapped in the sediments without long prior transport (parautochthonous).
\end{abstract}

Key words: Cenomanian-Turonian, early Eudicots, Ettingshausenia, Mikasa Formation, platanoid

\section{Introduction}

Angiosperms are the largest class of land plants and their species diversity is attributed mostly to the Eudicot diversification which followed the diversification of basal angiosperms (Chase et al., 1993; Soltis et al., 1999; APG II, 2003). Therefore, the Eudicot diversification, which occurred most intensely in the Albian to Cenomanian (Hickey and Doyle, 1977), transformed the earth's landscape.

Recent molecular phylogenetic studies incorporating multiple gene sequences indicate that the Eudicots would be further divided into the early-diverging Eudicots and the core Eudicots with the former grade including the Ranunculales and Proteales (Soltis et al., 2000; Kim et al., 2004). This order of diversification is concomitant with the paleobotanical records in which the early-diverging Eudicots and basal core Edicots, including platanoids or lower Hamamelidids, radiated in the mid-Cretaceous before the Eurosids and Euasterids (Hickey and Doyle, 1977; Crane et al., 1995). However, the nature of this diversification and the habitats of early platanoids or lower Hamamelidids are not well understood.

In contrast to the abundant records of mid-Cretaceous platanoids from Eurasia and North America, there is only one record known from this age in Japan: the wood of Plataninium jezoensis Ken. Takahashi and M. Suzuki from the Cenomanian to Turonian Middle Yezo Group of Hokkaido (Takahashi and Suzuki, 2003). Furthermore, despite extensive paleobotanical studies on Cretaceous plant fossils (e.g., Stopes and Fujii, 1910; Endo, 1925; Oishi, 1940; Matsuno et al., 1964; Nishida, 1991, 2005; Takahashi and Suzuki, 2003), little is known about mid-Cretaceous vegetation in Japan.

Here, we report platanoid leaves from the Cenomanian to Turonian Mikasa Formation of the Yezo Group, outcrop along the Pombetsu River, Mikasa City, Hokkaido (Figure 1). Their mode of occurrence and their significance are discussed.

\section{Geological setting of sample site}

\section{Geological outline}

The Cretaceous to Paleocene forearc basin-fill and accretionary complex are exposed across a $200 \mathrm{~km}$ wide and $400 \mathrm{~km}$ long belt in the mountainous spine of central Hokkaido (Ando, 2003; Takashima et al., 2004; Figure 1). The Cretaceous Yezo Group represents forearc basin sediments that accumulated on the east margin of the paleo-Asian continent (Figure 1). The platanoid leaves were collected from Pombetsu, Mikasa, central Hokkaido, Japan, where the Mikasa Formation of the Yezo Group outcrops (Figure 1). The Mikasa 


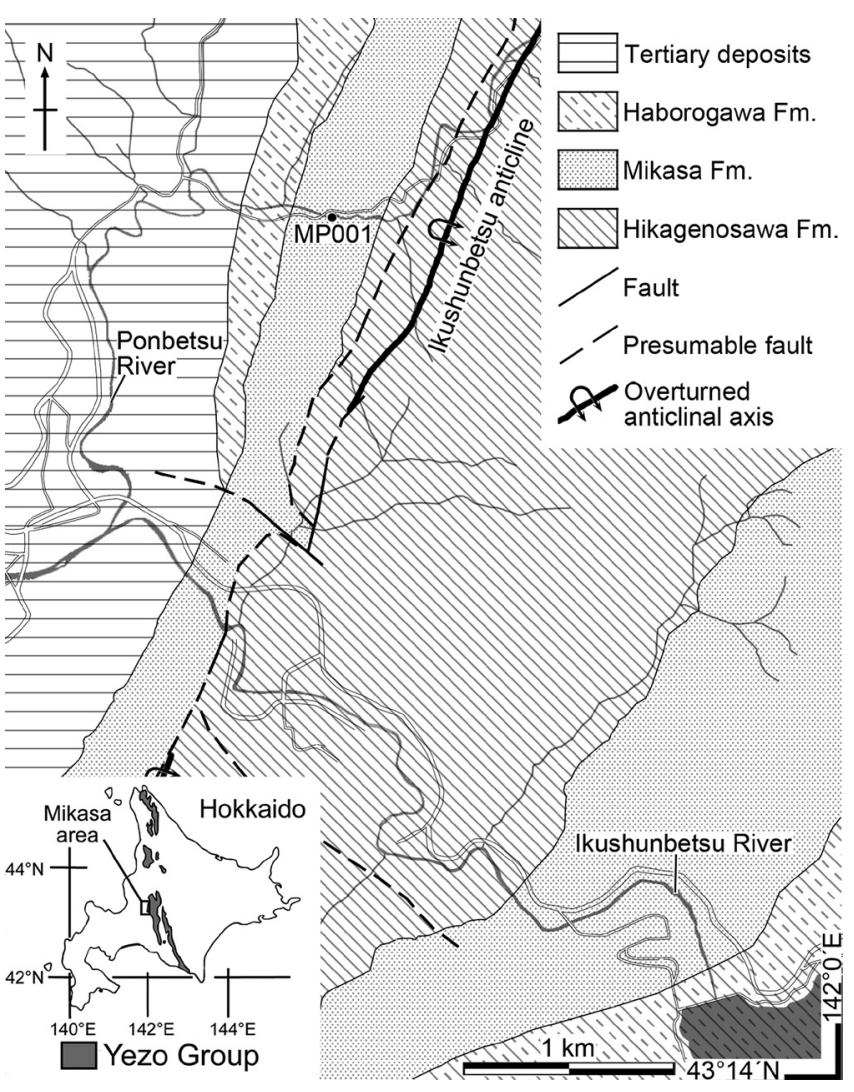

Figure 1. Geology of Mikasa area, central Hokkaido, Japan and sampling site of Mikasa Formation.

Formation is mainly distributed along the NNE-SSW trending Sorachi-Ikushunbetsu Anticline and the sample site is located in the western wing of the axis (Figure 1). Biostratigraphic studies of molluscan fossils suggest that the Mikasa Formation ranges from the Cenomanian (or late Albian) to the late Turonian (Ando, 1987, 1990a, b; Takashima et al., 2004). Westward-shallowing depositional environments are inferred in the Mikasa Formation (Ando, 1987, 1990a, b; Takashima et al., 2004).

The Mikasa Formation in the western wing of the Sorachi-Ikushunbetsu Anticline is divided into five units according to the sedimentary facies: Me, Twa, Twb, Twc, Twd (Matsuno et al., 1964; Ando, 1987, 1990a, b). The middle part of Twb, which is the coarsest unit of the Mikasa Formation, outcrops at location MP001. The Twb unit includes sediments deposited in swamp (or marsh) and shoreface (Ando, 1987, 1990a, b). The probable age of the Twb unit is the upper Cenomanian to the lower Turonian based on the age of the upper (Twa) and lower units (Twc) (Ando, 1987, 1990a).

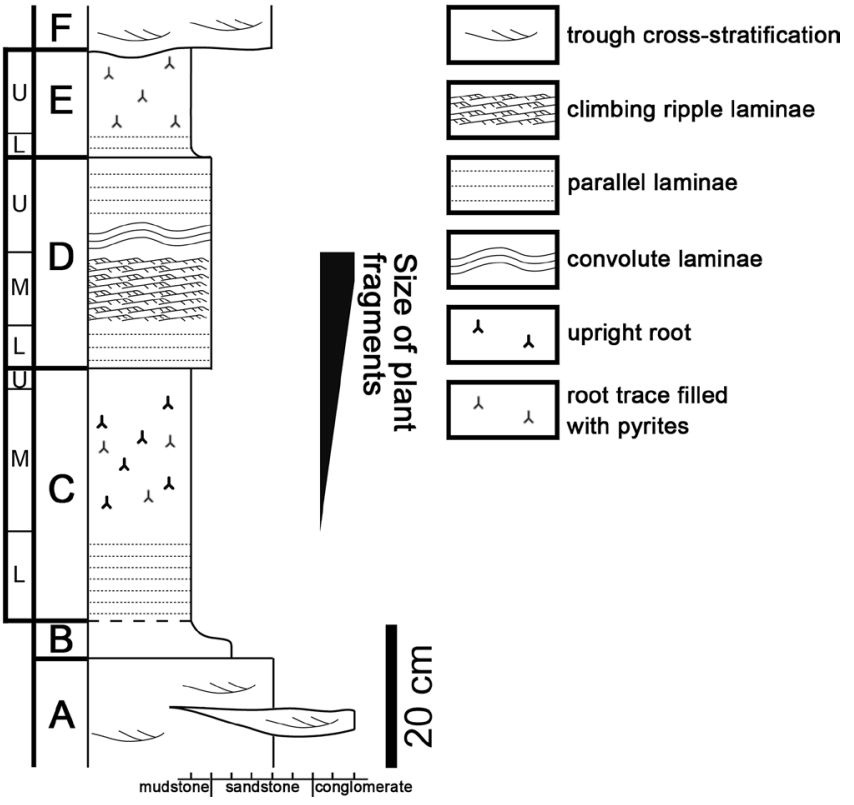

Figure 2. Columnar section of fluvial sediment outcrop at MP001. Boundary between bed B and C is indistinct (indicated by dashed line).

\section{Lithofacies of location MP001 and occurrence mode of plant fossils}

The sediments deposited in either swamp or marsh (Ando, 1987, 1990a, b) outcrop in location MP001 and are divided into six beds (A to F) in ascending order (Figure 2). Two cycles of flooding and subsequent soil formation are recognized (Bed $\mathrm{B}$ to $\mathrm{C}$ and $\mathrm{Bed} \mathrm{D}$ to E). Plant remains are contained in the horizons ranging from the middle part of Bed C to the middle part of Bed D (Figure 2). The plant remains become larger upward through those strata.

Bed A.-Medium-grained sandstone with trough cross-stratification and frequently intercalated pebblegraveled conglomerates $(<10 \mathrm{~cm})$.

Bed B.-5-cm thick carbonaceous very fine-grained sandstone grading upward to very-fine-grained sandstone of Bed $\mathrm{C}$ with an indistinct boundary between this bed and Bed C.

Bed C. $-35-\mathrm{cm}$ thick carbonaceous mudstone with weak parallel laminae in the lower part (up to $13 \mathrm{~cm}$ from bottom). Upright roots are frequent in the middle part (between 13 and $33 \mathrm{~cm}$ from bottom) with rich organic soil. Traces of these roots are often filled with pyrites (Figure 3A). Roots are rare in the upper part (above $33 \mathrm{~cm}$ from bottom). In the middle part, most of the plant litter has been fragmented into small pieces with an area of less than three square centimeters, although it can be identified as platanoid leaves from the char- 


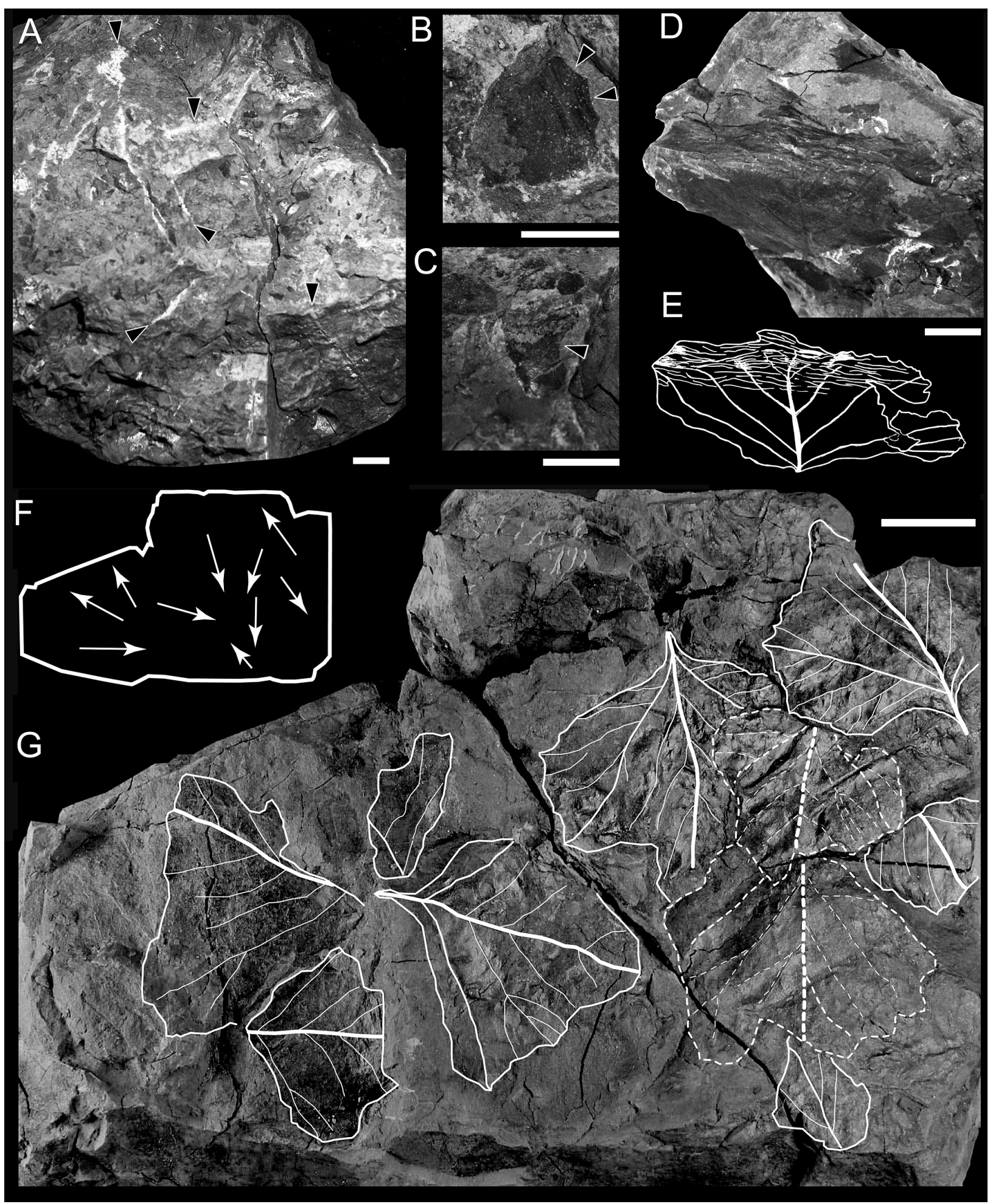

Figure 3. Occurrence mode of plant fossils. A. Traces of upright roots filled with pyrites (NSM-PP-9092). Each end of root fragment indicated by arrows. B, C. Sinuate margin and adjacent teeth of platanoid leaf fragments from middle part of Bed C (B. NSM-PP-9093. C. NSM-PP-9094). Sinus indicated by arrows. See Figures 5, 6. D. Folded platanoid leaves from upper part of Bed C (NSM-PP-9095). E. Line drawing of folded platanoid leaf in D. F, G. Block containing platanoid leaves (NSM-PP-9096). F. Schematic drawing of block in G. Apical direction of mid-vein of leaves indicated by arrows. G. Block containing platanoid leaves. Leaves traced by white line. Adaxial leaves indicated by solid line and abaxial leaves indicated by broken line. Scale bars: $\mathrm{A}-\mathrm{D}=1 \mathrm{~cm}, \mathrm{G}=5 \mathrm{~cm}$. 

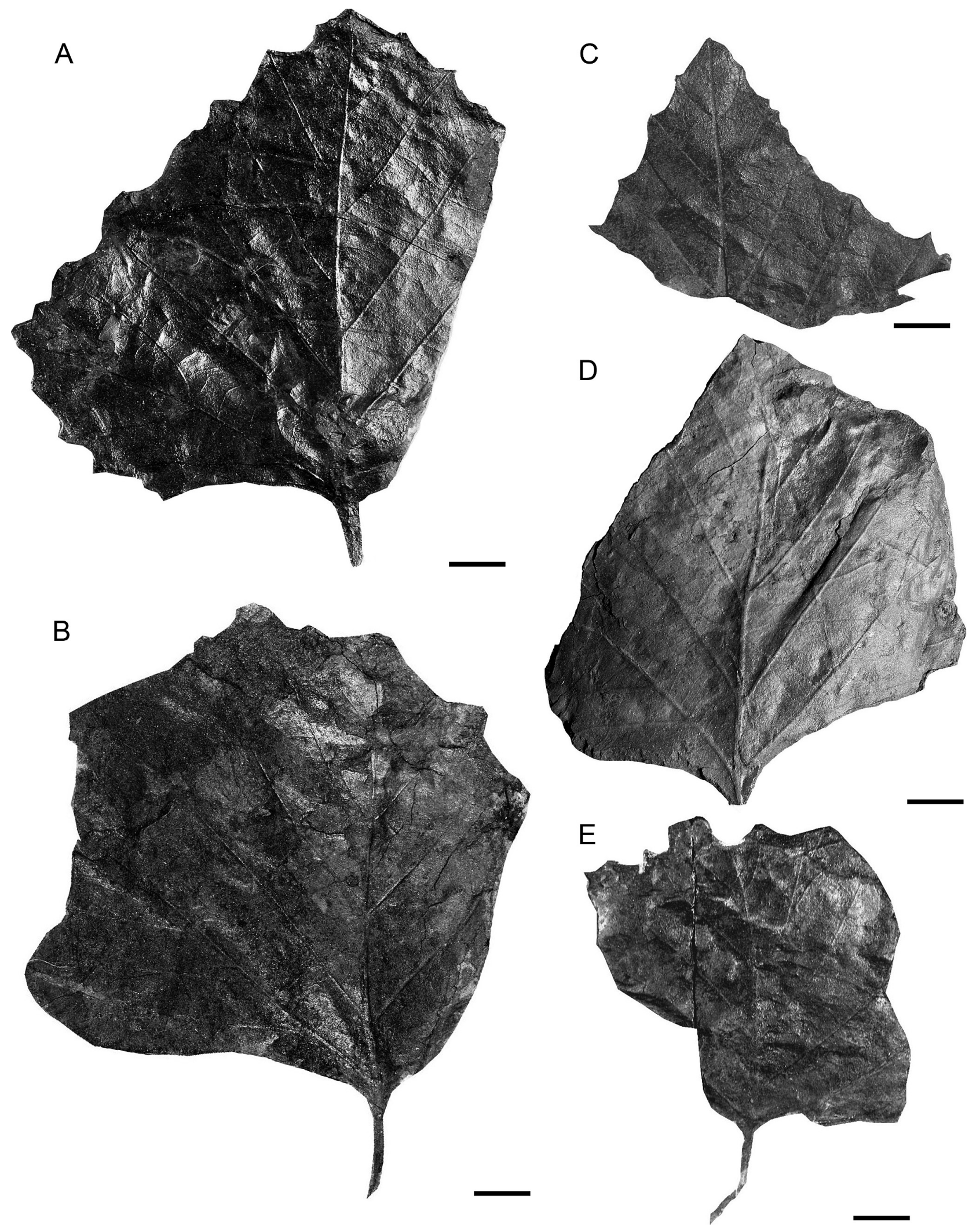

Figure 4. Platanoid fossils collected from Mikasa Formation. A. NSM-PP-9087. B. NSM-PP-9088. C. NSM-PP-9089. D. NSMPP-9090. E. NSM-PP-9091. Scale bars $=1 \mathrm{~cm}$. 


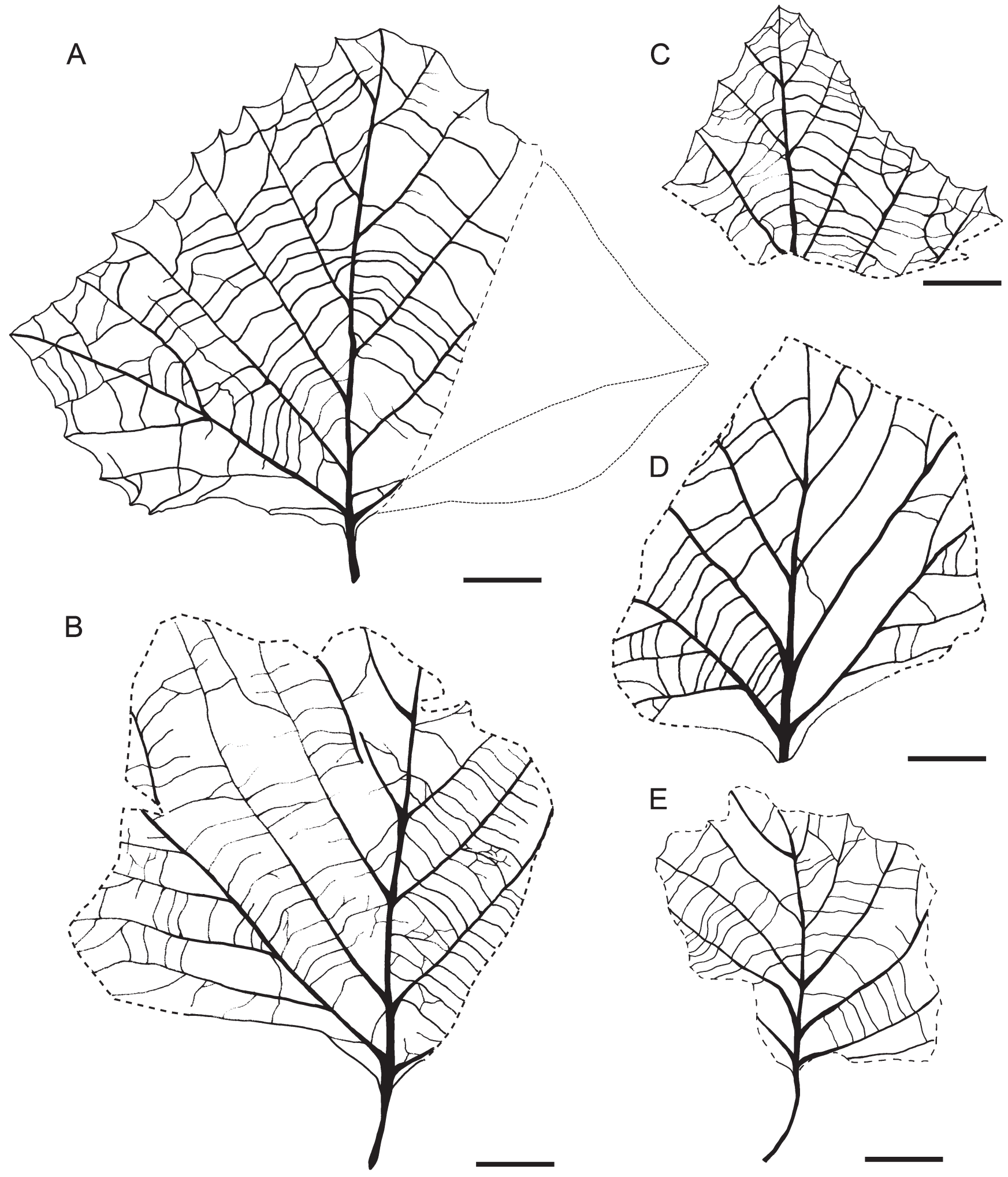

Figure 5. Line drawings of platanoid leaves in Figure 4. Scale bar $=1 \mathrm{~cm}$. 
acteristic features, such as sinuate margin with teeth or ladder-like venation formed by secondary and tertiary veins (Figures 3B, C). In the upper part, almost-intact platanoid leaves are condensed with many leaves curled or folded (Figures 3D, E) and encased in the sediments with the adaxial surface up. The sizes of the leaf fragments are less than 100 square centimeters.

Bed D. - 30-cm thick carbonaceous siltstone with parallel laminae in lower (up to $6 \mathrm{~cm}$ from bottom) and upper parts (down to $14 \mathrm{~cm}$ from top). Convolute laminae are often developed in the upper part. Climbingripple laminae are developed in the middle part (ranging 6 to $16 \mathrm{~cm}$ from bottom). In the lower part, the abundant platanoid leaves are less damaged than in Bed C. Leaf laminae are variously oriented (Figures 3F, G). Platanoid leaves are almost intact, thus the sizes of the leaf fragments are more than 100 square centimeters. In the middle part, many platanoid leaves are contained in the climbing-ripple laminae. In addition to the platanoid leaves, two small fragments of Anemia cf. dicksoniana frond were also obtained. The preservation is as good as in the lower part of Bed D and sizes of platanoid leaves are almost the same as those of the lower part of Bed D.

Bed E.-15-cm thick carbonaceous clay stone with weakly parallel laminae in the lower level up to $4 \mathrm{~cm}$ from bottom and rich organic soil in upper part (above $4 \mathrm{~cm}$ from bottom). The roots are disintegrated and the traces are filled with pyrites.

Bed F.-More than $1 \mathrm{~m}$ thick medium-grained sandstone with trough cross-stratification, eroding Bed E.

\section{Taxonomy}

\section{Class Magnoliophyte}

Genus Ettingshausenia Stiehler 1857

\section{Ettingshausenia cuneifolia (Bronn) Stiehler 1857}

Credneria cuneifolia Bronn, 1837, p. 583, pl. 28, figs. 11. Engelhardt, 1885, pl. 1, figs. 2, 7. Rüffle, 1968, p. 138, pl. 27, fig. 6; pl. 29, figs. $1-8$.

Platanus cuneifolia (Bronn) Kryshtofovich. Tanai, 1979, p. 108, pl. 12, fig. 12; pl. 13, figs. 9, 10; text-figs. 4, 5 .

Platanus (Credneria) heeri (Lesquereux) Krasilov, 1979, p. 112, pl. 47, figs. 1-4.

Specimens.-Figures 4A, 5A (NSM-PP-9087), 4B, 5B (NSM-PP-9088), 4C, 5C (NSM-PP-9089), 4D, 5D (NSM-PP-9090), 4E, 5E (NSM-PP-9091). All specimens are housed in the Paleobotanical Collections of National Museum of Nature and Science, Tokyo.

Description.-Obtained laminae variable in size, i.e., $3-16 \mathrm{~cm}$ in length and $3.5-17 \mathrm{~cm}$ in width. Petiole stout, 1 to $2 \mathrm{~cm}$ in length and $c a .0 .3 \mathrm{~cm}$ in width. Leaves unlobate or vestigially trilobate with crenate or broadly dentate margin. Teeth acuminate or attenuate and separated by arcuate sinus. Lamina (or lobe) apex obtuse in many specimens. Lamina base decurrent. Midvein stout, nearly straight, diverging into three lateral primary veins above laminar base in palinactinodromous orders (Figures 4, 5). Secondary veins diverged from primary veins at angles of $c a .40^{\circ}$, forked once or twice. Secondary and subsecondary veins terminated at teeth apex. Tertiary veins well developed over whole lamina and diverging at nearly right angles from secondary or subsecondary veins. Two adjacent secondary (or subsecondary) veins and tertiary veins between them form series of rectanglar loops. Distinct areoles formed by quarternary and tertiary veins, or only by quarternary veins.

Remarks. - The specimens can be referred to platanoid leaves based on the following characters: unlobate or vestigially trilobate laminar, dentate or crenate laminar margin, acuate sinus between teeth, decurrent laminar base, well-developed tertiary veins, ladder-like venation formed by secondary and tertiary veins, and palinactinodromous venation (Oishi and Huzioka, 1943; Hickey and Wolfe, 1975; Maslova et al., 2005). These external foliar morphologies are common to extant Platanus species, but exact relationship between such platanoid and extant genus Platanus has not been clarified (Rüffle, 1968, 1995; Maslova et al., 2005). Maslova et al. (2005) proposed the use of Ettingshausenia cuneifolia (Bronn) Stiehler as morphogenus for such Cretaceous and Paleocene platanoid leaves with uncertain phylogenetic affinity.

In Asia and Far East Russia, Ettingshausenia cuneifolia is also reported from the upper Santonian to Campanian Kuji Group (Tanai, 1979), although it is described as Platanus cuneifolia. Our specimens cannot be distinguished from platanoids collected from the Cenomanian "Upper" Formation of the Mifune Group in Kumamoto Prefecture, southwestern Japan (A. Narita, unpublished observation). Platanus (Credneria) heeri Lesquereux, from the Upper Cretaceous of Sakhalin (Krassilov, 1979), is also included in this species because it has palinactinodromous venation which is unlikely seen in Credneria species (Maslova et al., 2005). Kvaček and Váchová (2006) distinguished leaves with deltoid base from E. cuneifolia and assigned them to E. bohemica (Velenovský) Kvaček and Váchová. However, the difference in leaf base could be interspecific variation because extant platanaceous species exhibit considerable variations in leaf shape (Oishi and Huzioka, 1943; Denk, 2006). 


\section{Discussion}

It is suggested that the morphogenus Ettingshausenia would be related to the early-diversing eudicots or early-diversing core eudicots families, such as Platanaceae, Menispermaceae, and Hamamelidaceae (Rüffle, 1968, 1995; Maslova et al., 2005), although exact phylogenetic affinity of the morphogenus is uncertain. As illustrated by the abundant occurrence of Ettingshausenia species, diversification of Eudicots occurred in the northern hemisphere including northeastern Asia during the Albian to Turonian period (e.g., Hickey and Doyle, 1977, Sun et al., 2001; Maslova et al., 2005; Kvaček and Váchová, 2006). This report of Ettingshausenia cuneifolia from the Cenomanian to Turonian Mikasa Formation provides additional support for this scenario.

At location MP001, Ettingshausenia cuneifolia are concentrated in swamp or marsh deposits (Ando, 1987, $1990 \mathrm{a}, \mathrm{b})$. The leaves are degraded into small pieces in soil (middle part of Bed C) where the sediments are bioturbated by roots. On the contrary, they are best preserved in the second flooding horizon (lower and middle parts of Bed D) and underlying horizon (upper part of Bed C) where no roots were found. Scheihing and Pfefferkorn (1984) pointed out that bioturbation of sediments by roots and subsequent oxidization of plant litter would facilitate their degradation. This preservative difference found in the location MP001 also suggests that the avoidance of such disturb due to rapid burial contributes to the preservation of intact plant remnants.

We could not infer the exact habitat for Ettingshausenia cuneifolia in the land of the Mikasa Formation, but the exclusive occurrence of the same kind of leaves would imply that these litters are not transported far away from their sites of growth (Scheihing and Pfefferkorn, 1984; Ferguson, 1985; Gastaldo et al., 1996). Taking the sedimentary environments of the location MP001, their site of growth might have been close to either swamp or marsh where the leaves were trapped in sediments.

\section{Acknowledgements}

We thank K. Uemura and H. Nishida for their helpful advices and fruitful discussions. K. Kobayashi and N. Kobayashi kindly provided lodging facility. H. Kokubun helped our sampling. The Sorachi Forest Management Office and Mikasa City Museum permitted us to conduct our field survey in their dominations.

\section{References}

Ando, H., 1987: Shallow marine deposits in the Mikasa Formation of the Middle Yezo Group in Central Hokkaido - with special reference to hummocky cross stratification. Academic studies, Biology, Geology, School of Education, Waseda University, vol. 36, p. 20-32. (in Japanese with English abstract)

Ando, H., 1990a: Stratigraphy and shallow marine sedimentary facies of Mikasa Formation, Middle Yezo Group (Upper Cretaceous). Journal of the Geological Society of Japan, vol 96, p. 279-295. (in Japanese with English abstract)

Ando, H., 1990b: Shallow-marine sedimentary facies distribution and progradational sequences of the Mikasa Formation, Middle Yezo Group (Upper Cretaceous). Journal of the Geological Society of Japan, vol. 96, p. 453-469. (in Japanese with English abstract)

Ando, H., 2003: Stratigraphy correlation of Upper Cretaceous to Paleocene forearc basin sediments in Northeast Japan: cyclic sedimentation and basin evolution. Journal of Asian Earth Sciences, vol. 21, p. 921-935.

APG II, 2003: An update of the Angiosperm Phylogeny Group classification for the orders and families of flowering plants: APG II. Botanical Journal of the Linnean Society, vol. 141, p. 399-436.

Chase, M. W., Soltis, D. E., Olmstead, R. G., Morgan, D., Les, D. H., Mishler, B. D., Duvall, M. R., Price, R. Q., Hills, H. G., Qiu, Y.-L., Kron, K. A., Rettig, J. H., Conti, E., Palmer, J. D., Manhart, J. R., Sytsma, K. J., Michaels, H. J., Kress, W. J., Karol, K. G., Clark, W. D., Hedren, M., Gaut, B. S., Jansen, R. K., Kim, K.-J., Wimpee, C. F., Smith, J. F., Furnier, G. R., Strauss, S. H., Xiang, Q.-Y., Plunkett, G. M., Soltis, P. S., Swensen, S., Williams, S. E., Gadek, P. A., Quinn, C. J., Eguiarte, L. E., Golenberg, E., Learn, G. H. Jr., Graham, S. W., Barrett, S. C. H., Dayanandon, S. and Albert, V. A., 1993: Phylogenetics of seed plants: an analysis of nucleotide sequences from the plastid gene rbcL. Annals of the Missouri Botanical Garden, Vol. 80, p. 528-580.

Crane, P. R., Friis, E. M. and Pedersen K. R., 1995: The origin and early diversification of angiosperms. Nature, vol. 374, p. 27-33.

Denk, T., 2006: Leaf architecture in modern and fossil Platanaceae - Are there character states that can be used for family delimitation? In, Teodoridis V., Kvaček Z. and Kvaček J. eds., Abstracts of the 7th European Palaeobotany-Palynology Conference, Prague, p. 30. Prague National Museum, Prague.

Endo, S., 1925: Nilssonia-Bed of Hokkaido and its Flora. Science Reports of the Tohoku Imperial University, Second Series Geology, vol. 7, p. 57-72.

Engelhardt, H. 1885: Die Crednerien im untern Quader Sachsens. Festschrift der Naturwissenschaftlichen Gesellschaft ISIS in Dresden, Dresden, Jahrgang 1885, p. 55-62. (in German)

Ferguson, D. K., 1985: The origin of leaf-assemblages-New light on an old problem. Review of Palaeobotany and Palynology, vol. 46, p. $117-188$.

Gastaldo, R. A., Ferguson, D. K., Walter, H. and Rabold, J. M., 1996: Criteria to distinguish parautochthonous leaves in Tertiary alluvial channel-fills. Review of Paleobotany and Palynology, vol. 91, p. 1-21.

Hicky, L. J. and Doyle, J. A., 1977: Early Cretaceous fossil evidence for angiosperms evolution. The Botanical Review, vol. 43, p. 3104.

Hickey, L. J. and Wolfe, J. A., 1975: The base of angiosperm phylogeny: Vegetative morphology. Annals of the Missouri Botanical Garden, vol. 62, p. 538-589.

Kim, S., Soltis, D. E., Soltis, P. S., Zanis, M. J. and Suh, Y., 2004: Phylogenetic relationships among early-diverging eudicots based on four genes: were the eudicots ancestrally woody? Molecular Phylogenetics and Evolution, vol. 31, p. 16-30.

Kvaček, J. and Váchová, Z. 2006: Revision of platanoid foliage from the Cretaceous of the Czech Republic. Journal of the National Museum, Natural Histry Series, vol. 175, p. 77-89. 
Krassilov, V. A., 1979: The Cretaceous Flora of Sakhalin, 182 p. Publishing House Nauka, Moscow.

Maslova, N. P., Moiseeva, M. G., Herman, A. B. and Kvaček, J. 2005: Did plane trees exist in the Cretaceous? Paleontological Journal, vol. 4., p. 98-110. (in Russian)

Matsuno, K., Tanaka, K., Mizuno, A. and Ishida, M., 1964: Explanatory text of the Geological Map of Japan, Scale 1 : 50000, Iwamizawa, 179 p. (in Japanese with English abstract)

Nishida, H., 1991: Diversity and significance of Late Cretaceous permineralized plant remains from Hokkaido, Japan. Botanical Magazine, Tokyo, vol. 104, p. 253-273.

Nishida, H., 2005: Cretaceous plants of Japan based on permineralized fossils. Fossils (Palaeontological Society of Japan), vol. 78, p. 5-20. (in Japanese with English abstract)

Oishi, S., 1940: The Mesozoic floras of Japan. Journal of the Faculty of Sciences, Hokkaido Imperial University, Section 4, vol. 5, p. 123-480.

Oishi, S. and Huzioka, K., 1943: Studies on the Cenozoic Plants of Hokkaido and Karahuto VI. On the Tertiary Platanus from Hokkaido and Karahuto. Journal of the Faculty of Science, Hokkaido Imperial University, Series IV, vol. 7, p. 103-115.

Rüffle, L., 1968: Merkmalskomplexe bei älteren Angiospermen-Blättern und die Kutikula von Credneria Zenker (Menispermaceae). Palaeontographica, Series. B, vol. 123, p. 132-143. (in German)

Rüffle, L., 1995: Some artificial genera (Fagaceae, Platanaceae, Araliaceae) of Upper Cretaceous of the Northern Hemisphere and heterophylly in some modern hybrids. Palaeobotanist, vol. 44, p. 225-237.

Scheihing, M. H. and Pfefferkorn, H. W., 1984: The taphonomy of land plants in the Orinoco Delta: a model for the incorporation of plant parts in clastic sediments of Late Carboniferous age of
Euramerica. Review of Palaeobotany and Palynology, vol. 41, p. 205-240.

Soltis, D. E., Soltis, P. S., Chase, M. W., Mort, M. E., Albach, D. C., Zanis, M. J., Savolainen, V., Hahn, W. H., Hoot, S. B., Fay, M. F., Axtell, M., Swensen, S. M., Prince, L. M., Kress, W. J., Nixon, K. C. and Farris, J. S., 2000: Angiosperm phylogeny inferred from $18 \mathrm{~S}$ rDNA, $r b c L$, and $a t p B$ sequences. Botanical Journal of the Linnean Society, vol. 133, p. 381-461.

Soltis, P. S., Soltis, D. E. and Chase, M. W., 1999: Angiosperm phylogeny inferred from multiple genes as a tool for comparative biology. Nature, vol. 402, p. 402-404.

Stiehler, A. W., 1857: Beiträge zur Kenntniss der vorweltlichen flora des Kreidegebirges im Harze. Palaeontgraphica, vol. 5, p. 47-70, pls. 4-6. (in German)

Stopes, M. C. and Fujii, K., 1910: Studies on the structure and affinities of Cretaceous plants. Philosophical Transactions, Royal Society London, Series B, vol. 201, p. 1-90.

Sun, G., Zheng, S., Dilcher, D. L., Wang, Y. and Shengwu, M., 2001: Early angiosperms and their associated plants from western Liaoning, China. 227 p. Shanghai Scientific and Technological Education Publishing House, Shanghai.

Takahashi, K. and Suzuki, M., 2003: Dicotyledonous fossil wood flora and early evolution of wood characters in the Creteceous of Hokkaido, Japan. IAWA Journal, vol. 24, p. 269-309.

Takashima, R., Kawabe, F., Nishi, H., Moriya, K., Wani, R. and Ando, H., 2004: Geology and stratigraphy of forearc basin sediments in Hokkaido, Japan: Cretaceous environmental events on the northwest Pacific margin. Cretaceous Research, vol. 25, p. 365-390.

Tanai, T., 1979: Late Cretaceous floras from the Kuji District, Northeastern Honshu, Japan. Journal of Faculty of Science, Hokkaido University, Series IV, vol. 19, p. 75-136. 